\title{
p-BioSPRE - p-medicine Biospecimen Search and Project Request Engine
}

\author{
Christina Schröder , Tim Jüttner, Matthias Dobkowicz \\ From 1st Clinical Research Informatics (CRI) Solutions Day \\ Duesseldorf, Germany. 26-27 May 2014
}

\section{Characterisation}

Web-based tool, networking of biobanks for personalized medicine, metabiobank, provision of trans-institutional and trans-national access to biobanks.

\section{Description}

p-BioSPRE is a metabiobank providing trans-institutional and transnational access to biobanks (Figure 1) while safeguarding patients' privacy and full biobank autonomy [1].

The p-BioSPRE architecture is based on modular CRIP tools and concepts (a metadata-driven, scalable, and robust system of relational databases with an xmlbased query interface) [2]. It mirrors the hub-and-spokes structure proposed by BBMRI for national and international biobank networks. Contrary to biobank registries

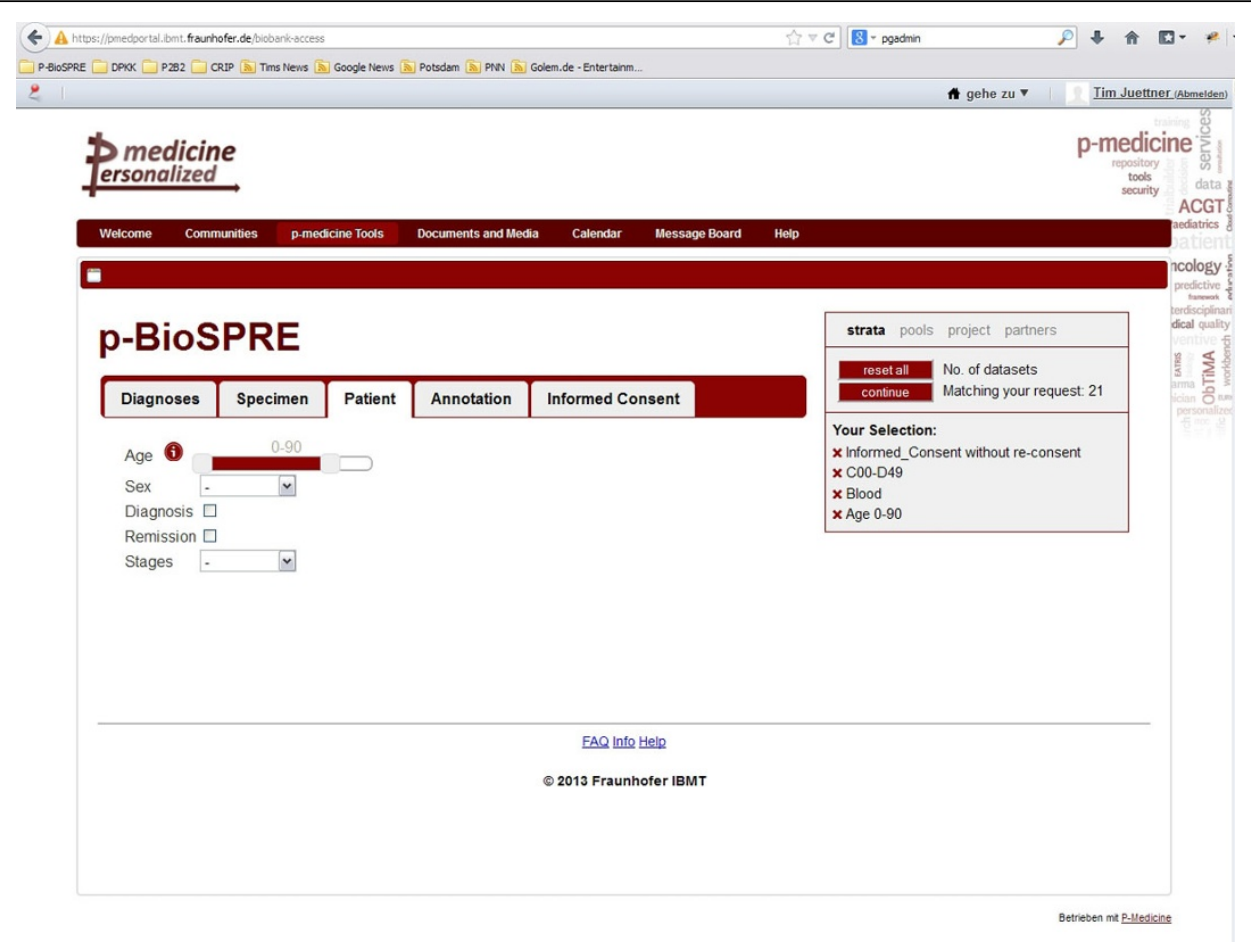

Figure 1 p-BioSPRE user interface displaying as example patients' age selection

\footnotetext{
* Correspondence: christina.schroeder@izi-bb.fraunhofer.de Fraunhofer IZI-BB, 14476 Potsdam, Germany

(c) 2015 Schröder et al; licensee BioMed Central Ltd. This is an Open Access article distributed under the terms of the Creative B. Wed Central Commons Attribution License (http://creativecommons.org/licenses/by/4.0), which permits unrestricted use, distribution, and (http://creativecommons.org/publicdomain/zero/1.0/) applies to the data made available in this article, unless otherwise stated.
} 
and catalogs, p-BioSPRE allows for up-to-date queries on a case-by-case and specimen-by-specimen basis. It caters to both: researchers looking for well-annotated human specimens from all disease areas and biobank operators conveniently offering donated specimens and data for research.

p-BioSPRE is in line with the BBMRI requirements for data integration systems and the p-medicine security framework. Its central infrastructure is maintained by Fraunhofer.

\section{Status of development}

Access to the operative version of $p$-BioSPRE is restricted to $\mathrm{p}$-medicine partners. The test and demo version 0.6 is on-line (links below) since May 23, 2014. Evaluation of $\mathrm{p}$-BioSPRE by $\mathrm{p}$-medicine clinical partners is ongoing until 2015.

\section{Users}

Researchers looking for stratified human specimens.

Biobank operators looking for projects and partners to make use of donated specimens and data.

\section{Links}

p-BioSPRE Demonstrator [https://preview-crip.fraunhofer. de/intern/demo/searchtool/search/p-biospre.cgi]; CRIP Toolbox [http://www.crip.fraunhofer.de/en/toolbox]

\section{Acknowledgement}

Supported by p-medicine (European Union's Seventh Framework

Programme for research, technological development and demonstration

under grant agreement No 270089).

Published: 22 May 2015

\section{References}

1. Schröder C, Heidtke KR, Zacherl N, Zatloukal K, Taupitz J: Safeguarding donors' personal rights and biobank autonomy in biobank networks: the CRIP privacy regime. Cell Tissue Bank 2011, 12(1):233-240.

2. Weiler $\mathrm{G}$, et al: p-BioSPRE - an information and communication technology framework for transnational biomaterial sharing and access. ecancer 2014, 8:401-419.

doi:10.1186/2043-9113-5-S1-S20

Cite this article as: Schröder et al:: p-BioSPRE - p-medicine Biospecimen Search and Project Request Engine. Journal of Clinical Bioinformatics 2015 5(Suppl 1):S20.

\section{Submit your next manuscript to BioMed Central} and take full advantage of:

- Convenient online submission

- Thorough peer review

- No space constraints or color figure charges

- Immediate publication on acceptance

- Inclusion in PubMed, CAS, Scopus and Google Scholar

- Research which is freely available for redistribution

Submit your manuscript at www biomedcentral.com/submit 